Fourth International Conference on Sustainable Construction Materials and Technologies http://www.claisse.info/Proceedings.htm

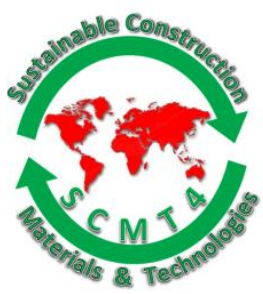

SCMT4

Las Vegas, USA, August 7-11, 2016

\title{
Sustainable Road Bases with Microbial Carbonate Precipitation
}

\author{
Hannah Porter ${ }^{1 a}$, Navdeep Kaur Dhami ${ }^{1 b}$, and Abhijit Mukherjee*1c \\ ${ }^{1}$ Department of Civil Engineering, Curtin University, Bentley, Western Australia 6102 \\ ${ }^{1 c}$ Email: <abhijit.mukherjee@curtin.edu.au>.
}

\begin{abstract}
The Australian road network is nearly a million kilometres long of which $83 \%$ can be classified as rural roads. The size and remote nature of Australia's road network poses unique challenges in terms of monitoring their condition as well as maintenance costs. Cement stabilisation is a practice commonly used in Australian road bases to improve their durability and avoid cost of inspection and repair. Due to the sheer length of the road network a huge quantity of cement is consumed in stabilisation work making the practice unsustainable. This paper explores a sustainable alternative through augmentation of traditional cement based stabilisation with microbial carbonate precipitation in Australian road base materials. Carbonate producing ureolytic strains of bacteria were isolated from Western Australian soil. Sand samples with a cement dosage of $7 \%$ have been subjected to microbial precipitation. The calcium carbonate crystals formed within the samples have been investigated by scanning electron microscopy and X-ray diffraction. Unconfined compressive strength (UCS) testing has been reported. Digital image correlation (DIC) technique has been utilised during UCS testing to extract more refined information such as local deformation and strain build up. The results show that microbial precipitation is able to significantly increase the strength of a cement stabilised material and can considerably improve the technological, economic and social sustainability of Australian road bases. A serendipitous spin off of this research is the discovery of the ability of DIC to predict the regions of failure of road base material at very early stages. DIC may provide a very useful tool for road asset management.
\end{abstract}

\section{INTRODUCTION}

Australia is a large continent with sparse population density. Connecting remote locations with road network has resulted in the country having the highest road length per population. Australian road network comprises of $873,573 \mathrm{~km}$ of roads of which $83 \%$ can be classified as rural roads (DoIRD 2015). Such a vast and remote road network creates a formidable problem in terms of monitoring deterioration as well as identification and prioritization of maintenance and rehabilitation works. In the past 10 years, (2005 2015) Australia has spent $\$ 21$ billion on road and bridge maintenance works alone (DoIRD 2015). Understandably, a durable road base system that would minimise the need for frequent inspection and maintenance has been opted for. Cement stabilisation is a practice commonly used in the Australian road industry for ensuring adequate strength and stiffness of a granular road base material. According to (Austroads 2006) it is common for the cost of the binder material (cement) in stabilisation works to be approximately $40 \%$ or greater of the total cost of the works. Typical energy consumption rates for cement stabilised materials have been estimated to be approximately $5,000 \mathrm{~mJ} /$ tonne while the actual placement and construction of the stabilised road base is estimated to consume only $50 \mathrm{~mJ} /$ tonne (Austroads 2007). 
Although the present road base has proved to be very functional, mandate on developing sustainable technologies necessitates drastically limiting its energy consumption and emission. Evidently, a sustainable binder for road base material with dramatically lower embodied energy and emission must be developed.

The Australian landscape has a large number of sustainable natural formations such as ant hills, corals and stromatolites. These structures too bind granular materials such as sand, but with a cement of negligible embodied energy. Recent research has revealed the role of microbes in cementing the natural formations such as stalagmites, stromatolites and corals (Chen, McKittrick et al. 2012). The process of natural cementation has been emulated in laboratory protocols known as Microbially Induced Calcium Carbonate Precipitation (MICP) (Stocks-Fischer, Galinat et al. 1999). MICP is a form of bio mineralisation where the metabolic products of microbes result in precipitation of calcium carbonate in presence of ionic calcium and a source of carbon (Castanier, Le Métayer-Levrel et al. 1999). The most remarkable feature of MICP is that unlike traditional cement the bio-cement is produced at ambient conditions with water as the solvent. Thus, it obviates the consumption of energy in cement manufacturing (Achal, Mukherjee et al. 2015). (Dejong, SOGA et al. 2013) report that a $\mathrm{kg}$ of soil has nearly $10^{12}$ microbes and many of them can be classified as calcifying. Thus, it is possible to harness the calcifying bacteria present in the soil of road bases for cementation action. MICP is an emerging technology for various geotechnical applications (DeJong 2014). It has also proved to be a very attractive measure to improve the engineering properties of all building materials (Achal and Mukherjee 2015). During the process of MICP bacteria within the soil digest nutrients and precipitate calcium carbonate. There are several different biological processes that can cause calcium carbonate precipitation to occur, however the process that occurs the fastest, and requires the least free energy, is precipitation via urea hydrolysis, (DeJong, Mortensen et al. 2010).

Laboratory experiments have demonstrated the potential of MICP in improvement of soil strength, (Le Métayer-Levrel, Castanier et al. 1999), (Whiffin, van Paassen et al. 2007), (Ferris, Stehmeier et al. 1996), reduction of permeability, (Harkes, van Paassen et al. 2010), stabilisation of slopes, (DeJong, Mortensen et al. 2010), (Harkes, van Paassen et al. 2010), improved resistance to liquefaction, (Burbank, Weaver et al. 2011) and also suppression of dust, (Chu J 2012). MICP forms "cohesive bridges" between grains of sand through the deposition of calcium carbonate crystals increasing the stiffness of the material and it also reduces permeability, (van Paassen, Daza et al. 2010). MICP was found to resist the deterioration of concrete in freeze thaw, sulphate attack and drying shrinkage (Ramachandran, Ramakrishnan et al. 2001). In case of reinforced concrete MICP retards moisture and chloride ion diffusion and corrosion of steel (Dhami, Reddy et al. 2012). Several progresses have been made in unravelling the biochemical processes (Castanier, Le Métayer-Levrel et al. 1999, Ercole, Bozzelli et al. 2012, Bains, Dhami et al. 2015), improving the bacterial strains (Achal, Mukherjee et al. 2009, Bergdale, Pinkelman et al. 2012), use of industry byproducts (Achal, Mukherjee et al. 2009, Dhami, Reddy et al. 2012), and process optimisation (Okyay and Rodrigues 2015, Dhami, Reddy et al. 2016). After the success of laboratory scale experiments in-situ soil strengthening at the field (bio-grouting) has been attempted where the biological fluid is injected in the soil. It has been observed that although the technique works well for surface treatments, coarse grained materials and mixed-in-place applications, in case of fine grained materials the injection well clogs rapidly, (Le Métayer-Levrel, Castanier et al. 1999). The optimum pressure to avoid clogging has been investigated and it was observed that a flow rate of $350 \mathrm{ml} / \mathrm{hr}$ could avoid clogging of a $5 \mathrm{~m}$ long tube, (Whiffin, van Paassen et al. 2007). (van Paassen, Daza et al. 2010) observed that in large scale experiments (treatment volume of up to $100 \mathrm{~m}^{3}$ ), use of bio-grouting is technically feasible under conditions common to what is found in practice (van Paassen 2009). Large scale laboratory tests on dike reinforcement using biocementation have already been carried out. (Burbank, Weaver et al. 2011) reported formation of around $1 \% \mathrm{CaCO}_{3}$ in near surface and 1.8- $2.4 \%$ calcite below $90 \mathrm{~cm}$ upon subjecting the soils on the shore Snake river, USA with ureolytic microbes.

Although MICP has shown a lot of promise the field trials must be implemented in a phased manner. Thus, it is advisable to apply MICP in Australian road bases in addition to cement stabilisers. Some challenges in 
the compatibility between cement stabilised soil and MICP are envisaged. The MICP process, on one hand, may impose restrictions on control of moisture in soil to achieve optimum consolidation, on the other hand, it may be affected by the high $\mathrm{pH}$ of cement. This paper reports performance of MICP as an augmentation to cement stabilised road base materials. A process of preparing MICP augmented stabilised road bases has been demonstrated. A method of testing the samples taking care of the scale effects is illustrated. It is noted that stabilisation increases carbonate precipitation at critical locations and thus, a small quantity of carbonate crystals improves the strength considerably. Microstructural analysis using scanning electron microscopy (SEM) and energy dispersive X-ray spectroscopy (EDS) has been performed to reveal the strengthening mechanism. Through digital image correlation the deformation and strain build up at the time of performing unconfined compression test has been monitored. It is discovered that DIC is able to pinpoint the local strain build up at early stages of loading. These locations ultimately cause cracking and collapse. Evidently, DIC has the potential to be a convenient technique for early identification of deterioration in the road surfaces and a useful road asset management tool.

MICP. During urea hydrolysis the bacteria within the soil metabolizes urea and produces ammonia $\left(\mathrm{NH}_{3}\right)$, and Carbon Dioxide $\left(\mathrm{CO}_{2}\right)$ within the cell (1). These chemicals diffuse through the bacterial cell wall into the surrounding pore space between soil grains. The ammonia $\left(\mathrm{NH}_{3}\right)$ reacts with water $\left(\mathrm{H}_{2} \mathrm{O}\right)$ to produce ammonium $\left(\mathrm{NH}_{4}\right)$ and hydroxyl ions $\left(\mathrm{OH}^{-}\right)(2)$ resulting in a corresponding increase in the $\mathrm{pH}$ of the solution while the carbon dioxide $\left(\mathrm{CO}_{2}\right)$ ) equilibrates to form bicarbonate $\left(\mathrm{HCO}_{3}\right)(3)$. In the presence of introduced calcium (attracted to the bacterial cell walls) the bicarbonate $\left(\mathrm{HCO}_{3}\right)$ then reacts with the hydroxyl ions $\left(\mathrm{OH}^{-}\right)$to precipitate calcium carbonate $\left(\mathrm{CaCO}_{3}\right)(4)$.

$$
\begin{aligned}
& \mathrm{NH}_{2}-\mathrm{CO}-\mathrm{NH}_{2}+\mathrm{H}_{2} \mathrm{O} \rightarrow 2 \mathrm{NH}_{3}+\mathrm{CO}_{2} \\
& 2 \mathrm{NH}_{3}+2 \mathrm{H}_{2} \mathrm{O} \rightarrow 2 \mathrm{NH}_{4}^{+}+2 \mathrm{OH}^{-} \\
& \mathrm{CO}_{2}+\mathrm{OH}^{-} \rightarrow \mathrm{HCO}_{3} \\
& \mathrm{Ca}^{2+}+\mathrm{HCO}_{3}+\mathrm{OH}^{-} \rightarrow \mathrm{CaCO}_{3}+\mathrm{H}_{2} \mathrm{O}
\end{aligned}
$$

\section{EXPERIMENTAL INVESTIGATION}

In this investigation, both standard methods of testing cement stabilised road base samples and the modified ones with MICP have been followed. In case of standard samples maximum compaction is achieved by maintaining an optimum moisture content and standard compaction technique on a sample of standard size. In case of MICP all the three conditions are violated. Thus, samples of three sizes have been prepared (Table 1). C100 are the standard samples in terms of size, moisture content and compaction. C65 are the intermediate scale samples that are not compacted according to the standard technique. C30 samples are smallest where neither the optimum moisture content nor the compaction has been followed. These samples are amenable to MICP. The samples have been tested for unconfined compression strength with digital image correlation. Their microstructure has been studied by SEM and EDS.

Materials. In case of standard samples the materials contained sand, cement and water. Manufactured sand sourced from Cook Industrial Minerals, Perth, Western Australia was used as the granular component of the mix. The particle size for the mix varied between $0.45 \mathrm{~mm}$ and $0.075 \mathrm{~mm}$ (Figure 1). The sand can be classified as a medium graded sand in accordance with ISO 14688, (ISO 2002). Commercially available general purpose grey cement sourced from Swan Cement, Perth, complying with AS3972, (AS 2010) and standard tap water have been utilised. In case of MICP, in addition to the above materials a bacterial strain (Bacillus Cereus S9.1), a nutrient fluid and a calcium source was used. 


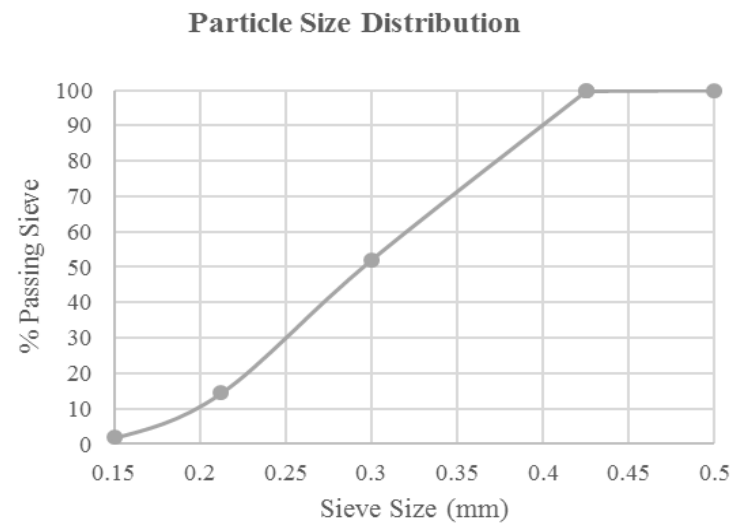

Figure 1. Particle Size Distribution for Manufactured Sand
Table 1. Summary of Test Specimens

\begin{tabular}{|l|l|l|l|}
\hline Identifier & Description & Diameter & $\begin{array}{l}\text { No. of } \\
\text { repeats }\end{array}$ \\
\hline C100 & $\begin{array}{l}\text { Cement } \\
\text { stabilised }\end{array}$ & $100 \mathrm{~mm}$ & 3 \\
\hline C65 & $\begin{array}{l}\text { Cement } \\
\text { stabilised }\end{array}$ & $65 \mathrm{~mm}$ & 2 \\
\hline C30 & $\begin{array}{l}\text { Cement } \\
\text { stabilised }\end{array}$ & $30 \mathrm{~mm}$ & 3 \\
\hline C30M & $\begin{array}{l}\text { Cement } \\
\text { stabilised }+ \\
\text { Microbes }\end{array}$ & $30 \mathrm{~mm}$ & 3 \\
\hline
\end{tabular}

Sample Preparation. The standard C100 samples were prepared in three steps- finding out the maximum dry density; preparing the samples through compaction and curing them. Cement was added at a proportion of 7\% (by mass) of sand. Maximum dry density of the cement-sand mixtures was obtained by finding the optimum moisture content according to AS 1289.5.2.1, (AS 2003). An optimum moisture content of around $10 \%$ by mass was found to achieve maximum compaction in the samples. Specimens were prepared by pouring the cement-sand mixture containing $10 \%$ water in a compacting cylinder and applying 25 blows per layer. The compaction was performed in five (5) even layers; and each layer was scarified to allow for good bonding between them. The samples were demoulded after 1 days and cured for 7 days in a humidity cabinet in accordance with standard practice for a cement stabilised material (Figure 2).

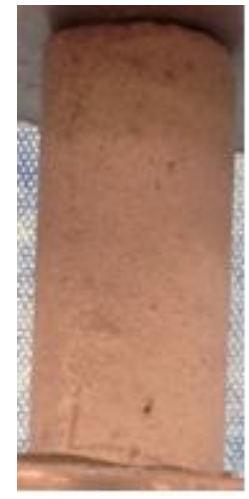

C30 Sample

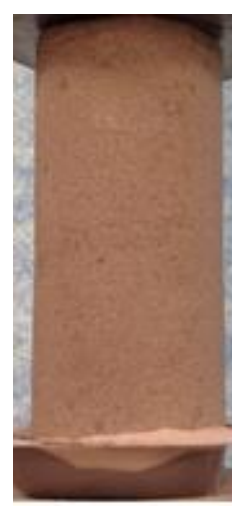

C65 Sample

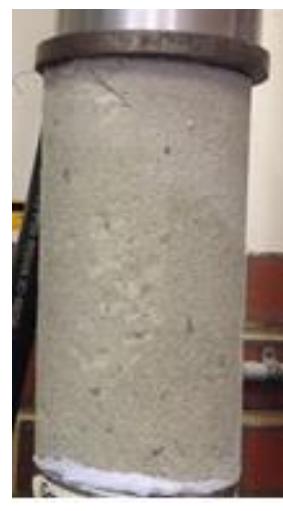

C100 Sample

Figure 2. Samples of different scales

C30M, C30 and C65 samples were prepared as follows. Cement was added at a proportion of 7\% (by mass) of sand. Water was added at a proportion of 10\% (by mass) to C30 and C65 samples. The bacterial solution was added at a proportion of $10 \%$ (by mass) to $\mathrm{C} 30 \mathrm{M}$ samples. Prior to mixing the bacterial solution was stabilised with Tris buffer to a PH 8.4. The optical density of the bacterial solution varied between OD600 $=1.252$ and OD600 $=1.924$. Specimens were prepared by pouring the mixture into cylinders and compacting. The compaction was performed in five (5) even layers and each layer was scarified to allow for good bonding. The samples were cured for 20 days in an incubator at a temperature of $37^{\circ} \mathrm{C}$. Each day 1 pore volume of cementation media was added to the samples. The cementation medium comprised of $0.5 \mathrm{M}$ urea, $0.5 \mathrm{M}$ calcium chloride and $3 \mathrm{~g} / 1$ Bacto nutrient broth. The cementation solution was autoclaved, prior to adding $0.5 \mathrm{M}$ urea. After autoclaving the solution was stabilised to a $\mathrm{PH}$ of between 8.0 and 8.5 . It 
should be noted that due to the addition of cementation fluid the optimum moisture content was not maintained for these specimens during the curing period. The optimum moisture content for MICP with cement stabilised materials has not been determined at this point of time.

Methodology. After the end of the curing period the specimens were tested for unconfined compression. UCS testing was performed on a universal testing machine (Shimadzu AGS - X) in accordance with AS 5101.4, (AS 2008). The specimens were placed vertically on the bottom platen. The bottom platen was lowered carefully to touch the top of the specimen but not stress it. It may be noted that these samples are highly susceptible to handling damages and end unevenness. Thus, careful placement of the samples is paramount for a good control of the tests. A digital camera was mounted in front of the specimen and snapshots were taken at regular interval while compressing the sample at a rate of $1 \mathrm{~mm} / \mathrm{minute}$. Open source Digital Image Correlation Matlab software (NCORR) was used to trace 2D displacement and strains throughout the deformation process. After UCS testing SEM and EDS analysis was undertaken on small portions of the samples. Samples were mounted on aluminium stubs and coated with a $10 \mathrm{~nm}$ thick carbon coating. SEM images and EDS were taken with a Zeiss Neon 40EsB dual beam FESEM/FIB-SEM.

\section{RESULTS AND DISCUSSIONS}

Scale Effect. The results of the control cylinders of three length scales are shown in Figure 3. They indicate an increase in strength with increasing cylinder size. Although smaller scale usually increases strength a reverse trend is noticed here due to the difference in compaction. C100 was fully compacted at optimum moisture content. However, in $\mathrm{C} 65$ the addition of cementation fluid during the curing process changed the moisture conditions. It is observed that there is a marginal reduction of compressive strength due to lack of compaction. In case of C30 the optimum moisture content too could not be maintained. In fact, in this case the specimens were supersaturated. As a result, the strength has decreased by nearly $25 \%$. It is known that soil expands in volume due to the buoyancy effect in supersaturated condition. Thus, the void space in soil is increased resulting in reduction in strength. This result also indicates that it may be wise to device MICP techniques with frugal water content where saturation can be avoided. The results of C30 samples are used later in determining the effect of MICP on UCS.

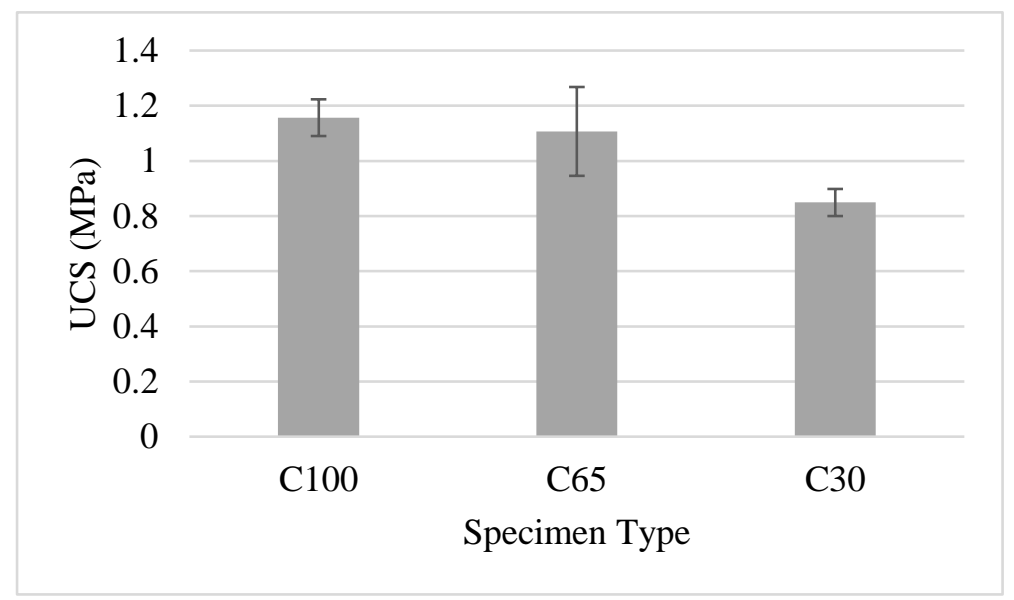

Figure 3. UCS Results for Control Samples of Varying Diameter

The failure modes were of two types. In one case vertical micro-cracks developed along the centre of the specimen. As the load increased the cracks coalesced and finally the specimen split into two halves (Figure 4a). In the second case the specimen bulged at a particular height, mainly in the top third, leading to collapse (Figure 4b). The failure mode was independent of the scale of the specimens. 


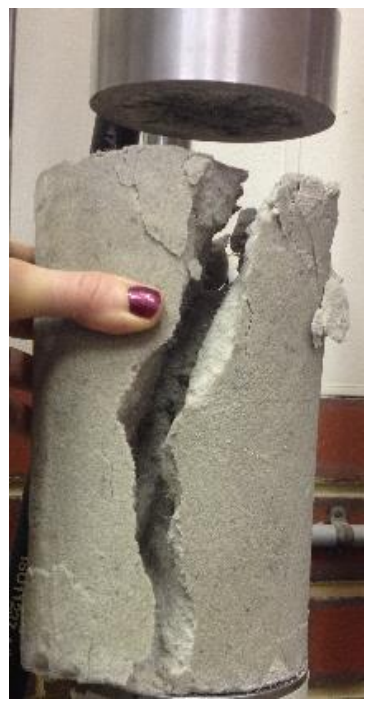

a. Failure in vertical cracking

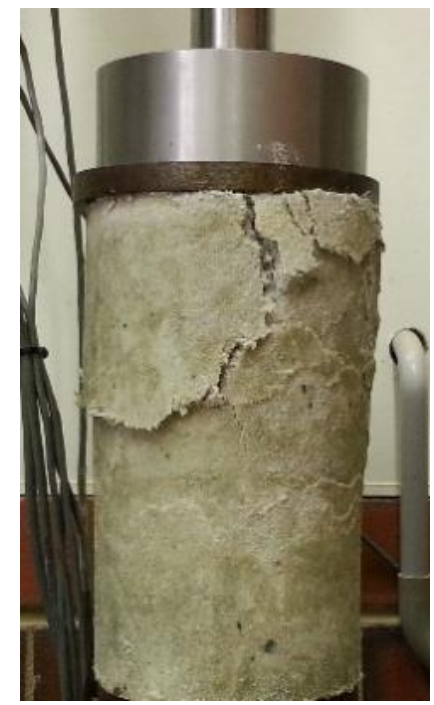

b. Head failure

Figure 4. Failure modes

Digital Image Correlation. The photographs taken during the UCS testing were utilised in DIC. Open source Digital Image Correlation Matlab software (NCORR) was used for the DIC analysis. Figure 4 shows the photographs and the corresponding DIC images of a C65 sample at three load steps. Two parameters, vertical deformation and vertical normal strain have been presented. Evidently, DIC provides very useful information of the variation of deformation and strain in the sample due to axial loading. The picture is far more detailed than was previously available through strain gauges. It can be seen that at $25 \%$ peak load no damage in the in the photograph is visible. However the DIC for vertical deformation indicates uneven deformation at the top of the sample. The strain DIC image amplifies the effect of uneven deformation and indicates large stress concentrations in the affected area. At $50 \%$ load capacity still there is no visible sign of damage in the photograph. In the deformation diagram a more uniform deformation at the top is noticed. Ostensibly, the surface roughness at the top has smoothed out due to localised redistribution of grains.

In photo 1 , (at $25 \%$ of the peak load) an initial unevenness can be observed in the displacement graph due to local stresses at the top of the specimen. This unevenness of loading is redistributed in the displacement graph for photo 2, (at 50\% of the peak load). At $100 \%$ of the peak load the displacement graph accurately shows the location of the visible crack within the specimen. In the strain plot, on the other hand the highly stressed zone (shown in blue) has spread to the left end of the specimen and there seems to be two zones of imminent damage developing. At the peak load a clearly visible crack appears in the photograph precisely in the area where the strain was shown to be high at a strain as low as $25 \%$. This is also the area where local unevenness was indicated by the deformation plot. The shape of the fragment matches very well with its shape in the corresponding deformation diagram. The strain in that area continues to be high. This experiment demonstrates the power of DIC in identifying future areas of distress when the load level is far lower than that at which the failure happens. While the deformation diagram captures the shape of the damaged area realistically the strain diagram amplifies the damaged area even at very low stress levels. The two diagrams in tandem are very useful in analysing the damage process of the specimens.

A serendipitous discovery of this experiment is the potential of DIC in monitoring the damages on road surfaces. Presumably, DIC will be able to locate the surface cracks on roads far ahead of the time they become visible and thus, enable early remedial action prior to substantial damage. The authors are engaged in testing the usefulness of this technique as a tool for asset management. 


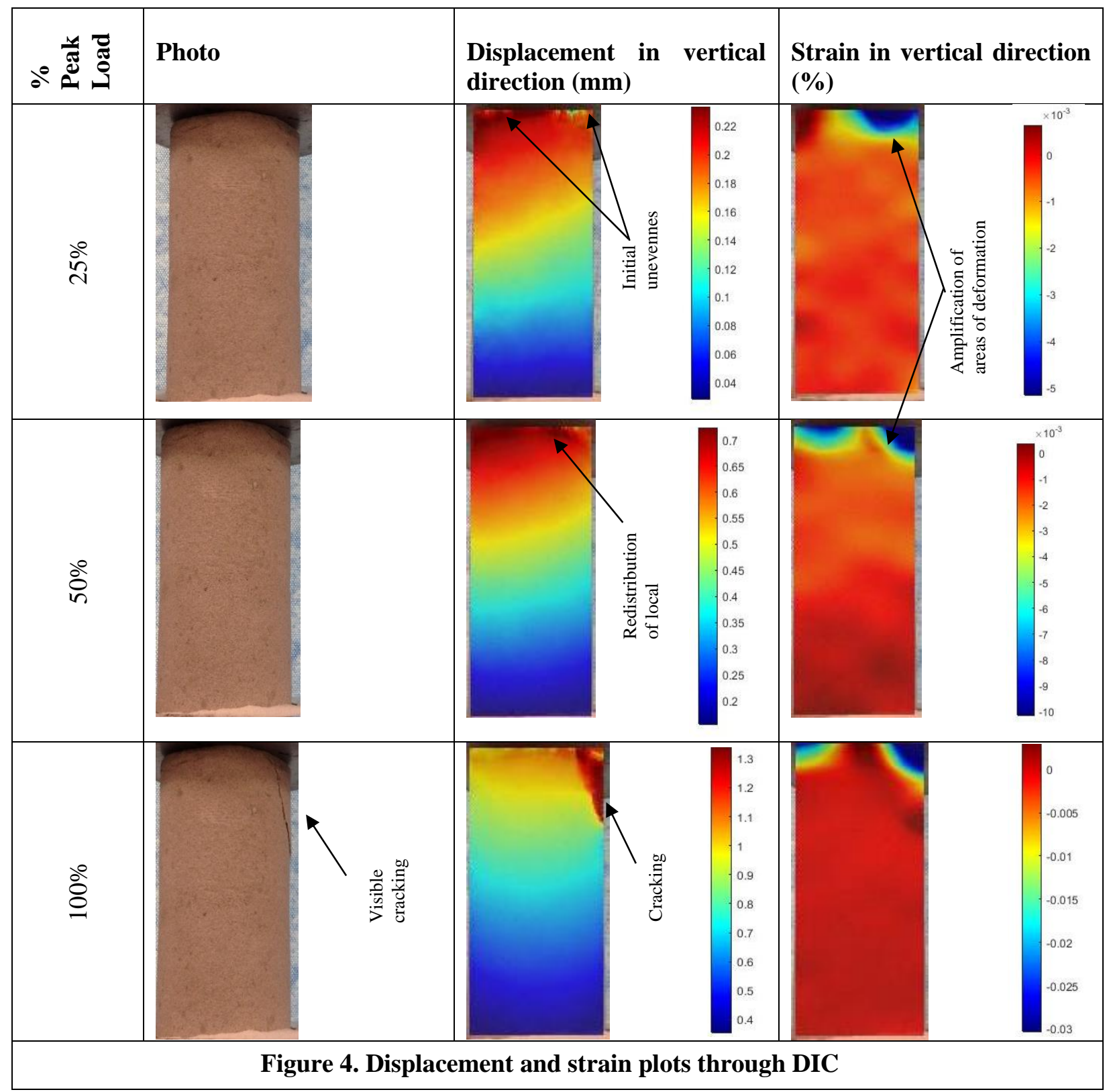

Effect of MICP. Next we report the effect of MICP on cement stabilised samples. UCS results for cement stabilised samples with and without MICP are shown in Table 2. A significant improvement, (in the order of 40\%), has been observed when combining cement stabilisation with MICP. The standard deviation was well within limit to predict this improvement with a fair degree of confidence.

Evidently, MICP can offer a huge benefit in cutting down cement consumption in road bases, and thus improve both economic and environmental sustainability. As mentioned previously, the cost of the binder material in stabilisation works can be equivalent or greater than $40 \%$ of the total cost of the stabilisation works (Austroads 2006), while the embodied energy in the cement binder $(5,000 \mathrm{~mJ} /$ tonne) is overwhelmingly the largest component in the for use in stabilised road base works (Austroads 2007). The use of MICP can really turn around the sustainability challenges that Australian road industry is facing. However, these are early results and the authors are aware several breakthroughs are imperative for successful field implementation of the technology. 
Table 2. UCS Results for Cement Stabilised Specimens with and without MICP

\begin{tabular}{|l|l|l|l|}
\hline Identifier & Description & $\begin{array}{l}\text { Average UCS } \\
(\mathbf{M P a})\end{array}$ & $\begin{array}{l}\text { Std. Deviation } \\
(\mathbf{M P a})\end{array}$ \\
\hline C30 & Stabilised with 7\% cement & $0.849 \mathrm{MPa}$ & \pm .05 \\
\hline C30M & Stabilised with 7\% cement + MICP & $1.326 \mathrm{MPa}$ & \pm .3 \\
\hline
\end{tabular}

Scanning Electron Microscopy. A microstructural analysis was undertaken to reveal the cause of the substantial increase of UCS due to MICP. It was decided to perform scanning electron microscopy coupled with energy dispersive X-ray spectroscopy to possibly identify the sand grains, the hydrated cement and the calcium carbonate particles. Figure 4 illustrates a typical micrograph with EDS of calcium carbonate deposits around a sand particle. The sand is identified by the abundance of silicon and oxygen in the EDS. A typical spectrum for calcium carbonate is also identified. It is noticed that the carbonate deposits take place at the acute corners created by the contacting grains of sand. Thus, instead of evenly spreading all over the surface of the sand grains MICP creates selective precipitation and thus, reinforces the material by preventing intergranular slip or rotation. This occurs because bacteria can safely attach themselves in the acute corners. Their metabolic activity in those corners results in nucleation and growth of calcium carbonate crystals in the critical areas and creates topologically optimal configuration of precipitation. Cement, on the other hand, coats the grains more evenly and thus only a fraction of it is effective in bonding the sand particle.

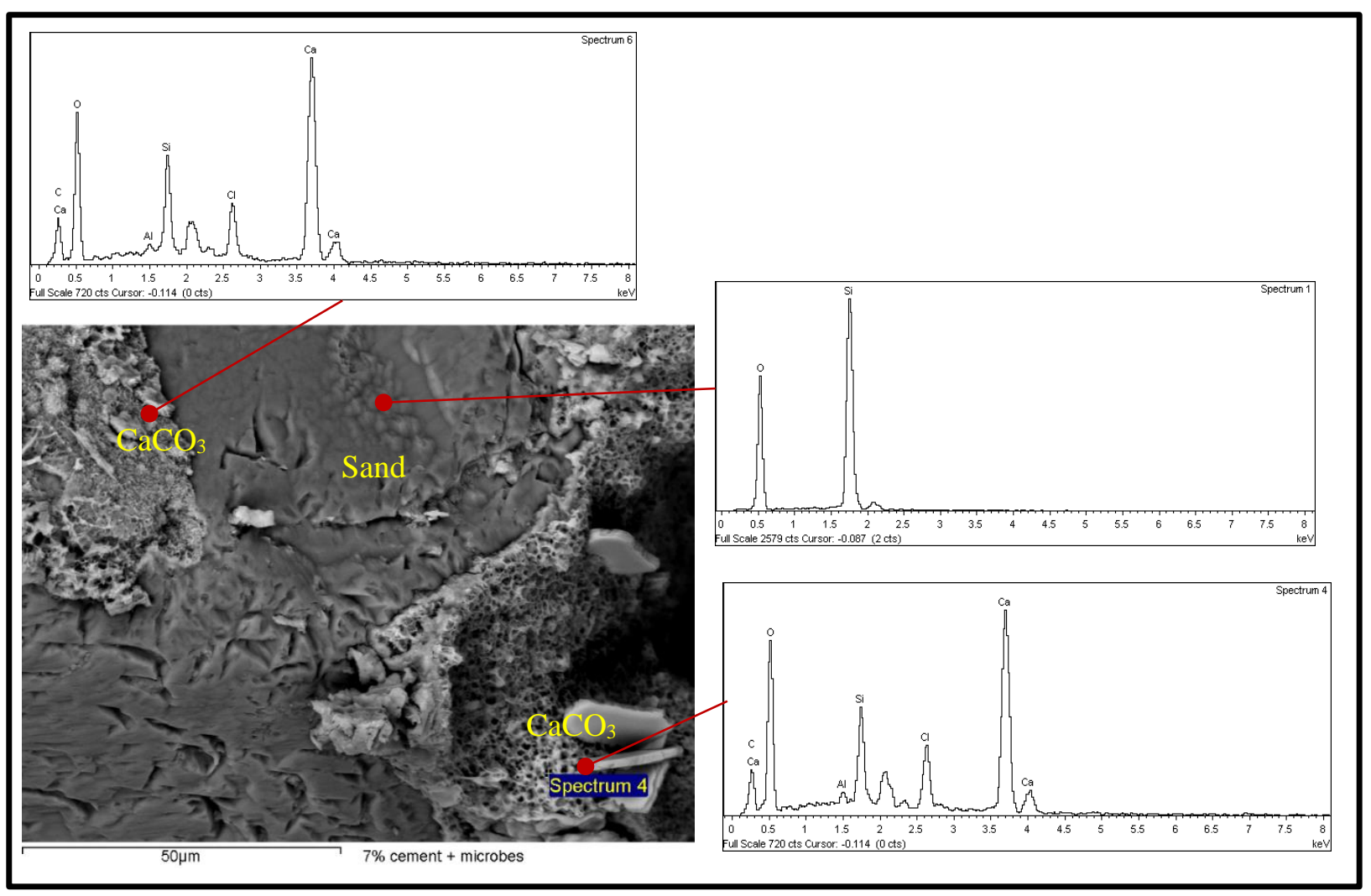

Figure 5. SEM and EDS of C30M samples

\section{CONCLUSION}

The investigations undertaken in this paper seek to determine the strength improvements that can be obtained by combining cement stabilisation with MICP. Key conclusions made from this investigation are as follows: 
1. It is important to consider the scale effect of samples for comparing the performance of MICP and conventional stabilisation

2. Saturation of soil due to MICP affects its compaction and UCS. An MICP technique that allows reduction of water to optimum moisture content level would be extremely beneficial.

3. MICP can be successfully used to improve the strength of cement stabilised materials. A $40 \%$ improvement in compressive strength was recorded in $30 \mathrm{~mm}$ diameter samples. It is likely that the strength of samples stabilised using both MICP and cement would increase with larger diameter samples.

4. DIC can be successfully used for observing the degradation process of cement stabilised materials. The use of both displacement and strain maps from DIC can provide an indication of where cracking is going to occur and may provide a useful asset management tool for road surfaces.

\section{ACKNOWLEDGEMENT}

The authors acknowledge the use of Curtin University's Microscopy \& Microanalysis Facility, whose instrumentation has been partially funded by the University, State and Commonwealth Governments.

\section{REFERENCES}

Achal, V. and A. Mukherjee (2015). "A review of microbial precipitation for sustainable construction." Construction and Building Materials 93: 1224-1235.

Achal, V., A. Mukherjee, P. C. Basu and M. S. Reddy (2009). "Lactose mother liquor as an alternative nutrient source for microbial concrete production by Sporosarcina pasteurii." J Ind Microbiol Biotechnol 36(3): 433-438.

Achal, V., A. Mukherjee, P. C. Basu and M. S. Reddy (2009). "Strain improvement of Sporosarcina pasteurii for enhanced urease and calcite production." J Ind Microbiol Biotechnol 36(7): 981-988.

Achal, V., A. Mukherjee, D. Kumari and Q. Zhang (2015). "Biomineralization for sustainable construction - A review of processes and applications." Earth-Science Reviews 148: 1-17.

AS (2003). AS 1289.5.2.1 - Methods of testing soils for engineering purposes. Method 5.2.1: Soil compaction and density tests - Determination of the dry density / moisture content relation of a soil using modified compactive effort. Sydney, NSW, Australia, Australian Standards.

AS (2008). AS5101.4 - Methods for preparation and testing of stabilised materials. Method 4: Unconfined compressive strength of compacted materials. Sydney, NSW, Australia, Standards Australia.

AS (2010). AS3972 - General purpose and blended cements. Sydney, NSW, Australia, Standards Australia.

Austroads (2006). Austroads Guide to Pavement Technology Part 4D: Stabilised Materials. Sydney, NSW, Australia, Austroads.

Austroads (2007). Austroads Guide to Pavement Technology: Part 4: Pavement Materials. Sydney, NSW, Australia, Austroads.

Bains, A., N. K. Dhami, A. Mukherjee and M. S. Reddy (2015). "Influence of exopolymeric materials on bacterially induced mineralization of carbonates." Appl Biochem Biotechnol 175(7): 3531-3541.

Bergdale, T. E., R. J. Pinkelman, S. R. Hughes, B. Zambelli, S. Ciurli and S. S. Bang (2012). "Engineered biosealant strains producing inorganic and organic biopolymers." J Biotechnol 161(3): 181-189.

Burbank, M. B., T. J. Weaver, T. L. Green, B. C. Williams and R. L. Crawford (2011). "Precipitation of 
Calcite by Indigenous Microorganisms to Strengthen Liquefiable Soils." Geomicrobiology Journal 28(4): 301-312.

Castanier, S., G. Le Métayer-Levrel and J.-P. Perthuisot (1999). "Ca-carbonates precipitation and limestone genesis — the microbiogeologist point of view." Sedimentary Geology 126(1-4): 9-23.

Chen, P.-Y., J. McKittrick and M. A. Meyers (2012). "Biological materials: Functional adaptations and bioinspired designs." Progress in Materials Science 57(8): 1492-1704.

Chu J, S. V., Ivanov V. (2012). "Microbially Induced Calcium Carbonate Precipitation on Surface or in the Bulk of Soil." Geomicrobiology Journal 29: 544-549.

DeJong, J. T., B. M. Mortensen, B. C. Martinez and D. C. Nelson (2010). "Bio-mediated soil improvement." Ecological Engineering 36(2): 197-210.

Dejong, J. T., K. SOGA, E. KAVAZANJIAN, S. BURNS, L. A. V. PAASSEN, A. A. QABANY, A. AYDILEK, S. S. BANG, M. BURBANK, L. F. CASLAKE, C. Y. CHEN, X. CHENG, J. CHU, S. CIURLI, A. ESNAULT-FILET, S. FAURIEL, N. HAMDAN, T. HATA, Y. INAGAKI, S. JEFFERIS, M. KUO, L. LALOUI, J. LARRAHONDO, D. A. C. MANNING, B. MARTINEZ, B. M. MONTOYA, D. C. NELSON, A. PALOMINO, P. RENFORTH, J. C. SANTAMARINA, E. A. SEAGREN, B. TANYU, M. TSESARSKY and T. WEAVER (2013) "Biogeochemical processes and geotechnical applications: progress, opportunities and challenges." Géotechnique 63, 287-301.

DeJong, J. Y., Martinez, B.C., Ginn, T.R., Hunt, C., Major, D., and Tanyu, B. (2014). "Development of a Scaled Repeated Five-Spot Treatment Model for Examining Microbial Induced Calcite Precipitation Feasibility in Field Applications." Geotechnical Testing Journal 37(3): 424-435.

Dhami, N., M. Reddy and A. Mukherjee (2012). "Biofilm and Microbial Applications in Biomineralized Concrete." In Advanced Topics in Biomineralization (Ed. Jong Seto) InTech: 137-164.

Dhami, N. K., M. S. Reddy and A. Mukherjee (2012). "Improvement in strength properties of ash bricks by bacterial calcite." Ecological Engineering 39: 31-35.

Dhami, N. K., M. S. Reddy and A. Mukherjee (2016). "Significant indicators for biomineralisation in sand of varying grain sizes." Construction and Building Materials 104: 198-207.

DoIRD (2015). Australian Infrastructure Statistics. D. o. I. a. R. Development. Canberra, Australia, Department of Infrastructure and Regional Development.

Ercole, C., P. Bozzelli, F. Altieri, P. Cacchio and M. Del Gallo (2012). "Calcium carbonate mineralization: involvement of extracellular polymeric materials isolated from calcifying bacteria." Microsc Microanal 18(4): 829-839.

Ferris, F. G., L. G. Stehmeier, A. Kantzas and F. M. Mourits (1996). "Bacteriogenic Mineral Plugging."

Harkes, M. P., L. A. van Paassen, J. L. Booster, V. S. Whiffin and M. C. M. van Loosdrecht (2010). "Fixation and distribution of bacterial activity in sand to induce carbonate precipitation for ground reinforcement." Ecological Engineering 36(2): 112-117.

ISO (2002). ISO14688 - 1 Geotechnical investigation and testing - Identification and classification of soil. Part 1: Identification and description. Switzerland, International Standards.

Le Métayer-Levrel, G., S. Castanier, G. Orial, J. F. Loubière and J. P. Perthuisot (1999). "Applications of bacterial carbonatogenesis to the protection and regeneration of limestones in buildings and historic patrimony." Sedimentary Geology 126(1-4): 25-34.

Okyay, T. O. and D. F. Rodrigues (2015). "Biotic and abiotic effects on CO2 sequestration during microbially-induced calcium carbonate precipitation." FEMS Microbiol Ecol 91(3).

Ramachandran, S., V. Ramakrishnan and S. Bang (2001). "Remediation of concrete using 
microorganisms." American Concrete Institute Material Journal 98: 3-9.

Stocks-Fischer, S., J. Galinat and S. Bang (1999). "Microbiological precipitation of $\mathrm{CaCO}_{3}$." Soil Biology Biochemistry 31: 1563-1571.

van Paassen, L. A., C. M. Daza, M. Staal, D. Y. Sorokin, W. van der Zon and M. C. M. van Loosdrecht (2010). "Potential soil reinforcement by biological denitrification." Ecological Engineering 36(2): 168175.

van Paassen, L. A., Harkes, M.P., van Zwieten, G.A., can der Zon, W.H., van der Star, W.R.L., van Loosdrecht., M.C.M. (2009). Scale up of BioGrout: a biological ground reinforcement method. 17th International Conference on Soil Mechanics and Geotehcnial Engineering, Alecandrina, Egypt, IOS Press.

Whiffin, V. S., L. A. van Paassen and M. P. Harkes (2007). "Microbial Carbonate Precipitation as a Soil Improvement Technique." Geomicrobiology Journal 24(5): 417-423. 